\title{
Peran Negara Dalam Menjaga Eksistensi Masyarakat Hukum Adat
}

\author{
Aryo Subroto \\ dewaavink@yahoo.co.id \\ Dosen Fakultas Hukum Universitas Mulawarman
}

\begin{abstract}
ABSTRAK
Kostitusi telah mengamanatkan kepada negara untuk mengakui dan menghormati kesatuan masyarakat hukum adat beserta segala hak-haknya. Terhadap amanat tersebut kemudian secara teknis dilaksanakan oleh pemerintah sebagai penyelenggara negara. Dalam tataran yuridis telah banyak produk hukum yang diundangkan oleh pemerintah dalam hal memberikan dasar kepastian hukum untuk memberikan ruang kepada masyarakat hukum adat dalam konteks untuk menjaga eksistensi mereka. Namun hal itu, belum memberikan jaminan dalam tataran praktek bagi terjaganya eksistensi masyarakat hukum adat, konflik-konflik yang berimbas pada terampasnya hak masyarakat hukum adat masih marak terjadi. Hingga pada tahun 2014 lalu pemerintah melalui kementerian dalam negeri mengeluarkan Permendagri Nomor 52 tahun 2014 tentang Pedoman Pengakuan dan Perlindungan Masyarakat Hukum Adat, permendagri ini kemudian cukup memberi harapan bagi masyarakat hukum adat dalam hal membantu untuk menjaga eksistensi mereka melalui penetapan kepala daerah.
\end{abstract}

Kata Kunci: Eksistensi Masyarakat Hukum Adat, Negara, Permendagri 52/2014.

\begin{abstract}
The constitution has mandated the state to recognize and respect to indigenous peoples unity and their rights. This mandate is technically carried out by the government as a state administrator. At the juridical level, there are many legal products disseminated by the government as a basis for legal certainty to provide space for indigenous peoples in the context of maintaining their existence. However, at the practice level there is no guarantee of the existence of indigenous peoples, conflicts that result in the loss of indigenous peoples' rights are still prevalent. Until 2014, the Ministry of Home Affairs issued Minister of Home Affairs Regulation No. 52 of 2014 on The guidelines for Recognition and Protection of Indegenous people unity. This regulation gives hope to indigenous people to maintain their existence through the determination of regional heads.
\end{abstract}

Keywords : Indigenous peoples unity, State, Minister of Home Affairs Regulation No. 52 of 2014 


\section{PENDAHULUAN}

\section{Latar Belakang}

Sejarah telah mencatat bahwa keberadaan Masyarakat Hukum Adat di tanah air jauh sebelum Bangsa Indonesia diproklamirkan dan merdeka. Pada masa itu kejayaan masyarakat hukum adat dapat ditelusuri melalui penguasaan wilayah yang mereka diami, keberadaan hukum adat yang mengatur dan mempengaruhi kehidupan sosial masyarakat hukum adat, keberadaan lembaga adat yang tidak hanya sekedar sebagai lembaga yang diisi oleh para pemuka adat tetapi juga sebagai pengawal pemberlakuan hukum adat yang ada yang kesemuanya hingga kini masih terlihat di beberapa wilayah di Indonesia.

Dalam literatur dan peraturan perundang-undangan terdapat dua penyebutan istilah masyarakat adat, yaitu ada yang menyebutnya masyarakat adat dan ada juga yang menyebutnya masyarakat hukum adat. Walaupun demikian, perbedaan peristilahan tersebut tidak menafikkan atau menegaskan hak-hak adat yang dimiliki oleh masyarakat yang bersangkutan ${ }^{1}$. Istilah masyarakat adat digunakan untuk merujuk masyarakat asli yang ada di Indonesia, namun ada pula istilah lain yang digunakan seperti masyarakat hukum adat atau penduduk pribumi, dimana istilah ini mengandung makna yang sama.

Aliansi Masyarakat Adat Nusantara (AMAN) pada tahun 1999 dalam kongresnya yang pertama menetapkan pengertian masyarakat adat adalah komunitas-komunitas yang hidup berdasarkan asal usul leluhur secara turun temurun di atas suatu wilayah yang memiliki adat, yang memiliki kedaulatan atas tanah dan kekayaan alam, kehidupan sosial budaya yang diatur oleh hukum adat

\footnotetext{
1 Sumardjani, Lisman, Konflik Sosial Kehutanan,
} Bogor, 2007 Hal 1. dan lembaga adat yang mengelola keberlangsungan kehidupan masyarakatnya. Istilah masyarakat adat mulai mendunia setelah pada tahun 1950-an International Labour Organization (ILO) mempopulerkan isu indigenous peoples atau masyarakat adat. Setelah dihembuskan oleh ILO sebagai isu global kemudian Word Bank juga mengadopsi isu tersebut untuk proyek pendanaan pembangunan disejumlah negara, malalui kebijakan OMP (1982) dan OD ( 1991), terutama di tiga negara yaitu Amerika Latin, Afrika, dan Asia Pasifik. Mencuatnya isu masyarakat adat berawal dari berbagai gerakan protes masyarakat asli (native peoples) di Amerika Utara yang meminta keadilan pembangunan, setelah kehadiran sejumlah perusahaan transnational di bidang pertambangan beroperasi di wilayah kelola mereka dan pengembangan sejumlah wilayah konservasi oleh pemerintah AS dan Kanada. $^{2}$

Khusus di Indonesia, keberadaan masyarakat hukum adat sudah mendapatkan jaminan melalui konstitusi, jaminan ini sebagaimana yang diatur dalam pasal 18B ayat 2 Undang-Undang Dasar Negara Republik Indonesia menegaskan bahwa "Negara mengakui dan menghormati kesatuan-kesatuan masyarakat hukum adat beserta hak-hak tradisionalnya sepanjang masih hidup dan sesuai dengan perkembangan masyarakat dan prinsip negara kesatuan Republik Indonesia yang diatur dalam Undang-undang".

Oleh karenanya, baik masyarakat adat atau masyarakat hukum adat atau penduduk asli atau istilah lain yang digunakan oleh masyarakat itu sendiri, sepanjang berada dalam wilayah Indonesia

${ }^{2}$ Siradjudin, Azmi A. R., Pengakuan Masyarakat Adat dalam Instrumen Hukum Nasional, Yayasan Merah Putih. Sulawesi Tengah, 2010. Hal 1. 
wajib dilindungi oleh negara sebagai suatu institusi kekuasaan tertinggi. Perlindungan yang dimaksud dalam rangka memberikan jaminan terhadap warga negara baik pada hak-hak pribadi, kelompok maupun masyarakat adat termasuk eksistensinya. Hal ini dimaksudkan untuk melindungi seluruh warga negara dalam bingkai kepentingan bersama (kolektif). Perlindungan tersebut mencakup segala aspek baik kepercayaan, budaya, ekonomi, sosial maupun politik. Kesemuanya dapat ditelusuri dalam realitas pengaturan interaksi diantara masyarakat adat yang terefleksi dalam hukum adat mereka.

Di Indonesia, eksistensi masyarakat hukum adat mendapat tantangan yang cukup besar dari berbagai hal dan pihak, mulai dari persoalan sosial yang dihadapi berkaitan dengan masuknya budaya-budaya asing yang dapat menggerus budaya lokal yang selama ini hidup dan menghidupi masyarakat hukum adat, hingga pada persoalan yang kerap menimbulkan konflik yang berkepanjangan seperti "perampasan" wilayah adat (teritorial) baik oleh pihak swasta (korporasi) maupun oleh negara sendiri.

Konflik tentang "pencaplokan" wilayah adat oleh perusahaan/korporasi baik yang bergerak di bidang perkebunan, pertambangan maupun bidang-bidang lainnya belakangan ini kian marak terjadi. Hampir pada seluruh daerah di tanah air yang terdapat masyarakat hukum adat mengalami hal yang demikian. Dalam kondisi tersebut tidak jarang posisi masyarakat hukum adat berada pada posisi yang lemah baik secara hukum maupun secara politik. Ironisnya selain swasta, pemerintah juga turut andil dalam berbagai macam konflik yang mengorbankan hakhak masyarakat hukum adat, sebagaimana yang kita ketahui bahwa melalui UndangUndang Nomor 41 tahun 1999 tentang Kehutanan, negara telah "merampas" hak masyarakat hukum adat atas pengelolaan hutan adat yang hingga akhirnya tahun 2012 Mahkamah Konstitusi mengembalikan hak yang semestinya berada ditangan masyarakat hukum adat melalui putusan Nomor 35/PUU-X/2012 yang menegaskan kembali bahwa Hutan Adat adalah hutan yang berada dalam wilayah masyarakat adat, dan bukan lagi sebagai hutan negara.

Uraian paragraf di atas menunjukan beberapa persoalan yang dapat menggerus dan mengancam eksistensi masyarakat hukum adat di tanah air. Hal ini menunjukkan bahwa implementasi dari pasal 18B ayat 2 Undang-Undang Dasar Negara Republik Indonesia belum sepenuhnya terlaksana atau dalam istilah lain pemerintah belum konsisten dalam menjalankan amanah yang diberikan oleh konstitusi. Oleh karena itu, perlu kiranya kita mengetahui sebenarnya seperti apa peran yang sudah dilakukan oleh negara dalam menjaga eksistensi masyarakat hukum adat di Indonesia melalui kewenangan yang dimiliki.

\section{Rumusan Masalah}

Berdasarkan uraian dalam latar belakang tersebut di atas, maka yang menjadi fokus permasalahan dalam penelitian ini adalah bagaimana peran Negara dalam menjaga eksistensi Masyarakat Hukum Adat?

\section{Tujuan Dan Kegunaan Penelitian}

Adapun tujuan dan kegunaan dari penelitian ini adalah untuk mengetahui sejauh mana peran negara dalam menjaga eksistensi masyarakat hukum adat. Adapun keguanaannya adalah dapat memberikan pemahaman bagi kita terutama stakeholder mengenai peran negara dalam menjaga eksistensi masyarakat hukum adat. 


\section{METODE PENELITIAN}

\section{Jenis penelitian}

Metode penelitian hukum merupakan suatu cara yang sistematis dalam melakukan sebuah penelitian. ${ }^{3}$ Penelitian hukum normatif (normative law research) menggunakan studi kasus normatif berupa produk perilaku hukum, misalnya mengkaji undang - undang. Pokok kajiannya adalah hukum yang dikonsepkan sebagai norma atau kaidah yang belaku dalam masyarakat dan menjadi acuan perilaku setiap orang. Sehingga penelitian hukum normatif berfokus pada inventarisasi hukum positif, asas-asas dan doktrin hukum, penemuan hukum dalam perkara in concreto, sistematik hukum, taraf sinkronisasi, perbandingan hukum dan sejarah hukum. ${ }^{4}$

Dalam penulisan ini jenis penelitian yang di gunakan adalah jenis penelitian hukum normatif, di mana pada uraian di atas dijelaskan bahwa penelitian hukum normatif merupakan penelitian hukum yang dilakukan dengan menggunakan pendekatan perundang-undangan, bukubuku, jurnal, makalah serta pendapat para ahli hukum yang berkaitan dengan masyarakat hukum adat.

\section{Pendekatan penelitian}

Pendekatan penelitian adalah metode atau cara mengadakan penelitian. ${ }^{5}$ Sesuai dengan jenis penelitiannnya yakni penelitian hukum normatif (yuridis normatif), maka dapat digunakan lebih dari satu pendekatan. ${ }^{6}$ Dalam penelitian ini

\footnotetext{
3 Abdulkadir Muhammad, Hukum Dan Penelitian Hukum (Bandung: PT. Citra Aditya Bakti,2004), 57. 4 Abdulkadir Muhammad. 2004. Hukum dan Penelitian Hukum. Cet. 1. Bandung: PT. Citra Aditya Bakti. Hal. 52

5 Suharsimi Arikunto,Prosedur Penelitian: Suatu Pendekatan Praktek (Jakarta: Rieneka Cipta, 2002), 23.

6 Jhonny Ibrahim, Teori dan Metodologi Penelitian Hukum Normatif ( Malang: Bayumedia Publishing, 2006),46.
}

digunakan pendekatan perundang-undangan (Statute Approach) dan pendekatan konsep (conceptual approach). ${ }^{7}$ Yaitu pendekatan yang dilakukan dengan membaca literature dan peraturan perundang-undangan. Analisis terhadap bahan-bahan hukum yang telah diperoleh dilakukan dengan cara deskriptif, analis dan argumentatif.

\section{Jenis Dan Sumber Bahan Hukum}

Adapun dalam penelitian ini jenis dan bahan hukum yang digunakan yaitu meliputi bahan hukum primer yaitu bahanbahan yang mengikat terdiri dari UndangUUD 1945, Undang-undang, Perppu, Peraturan Pemerintah, Peraturan Presiden, Peraturan Menteri, dan jenis peraturan hukum lainnya yang berkaitan dengan masyarakat hukum adat.

Adapun yang Jenis Bahan Hukum Sekunder yaitu bahan hukum yang menunjang dan memberikan penjelasan mengenai bahan hukum primer berupa karya ilmiah, skripsi, tesis, disertasi, penjelasan-penjelasan pemerintah dan sebagainya yang relevan dengan masyarakat hukum adat. Dan Bahan Hukum Tersier yaitu bahan hukum yang memberikan petunjuk maupun penjelasan terhadap bahan hukum primer dan bahan hukum sekunder, yaitu kamus hukum, ensiklopedia, dan lain-lain.

\section{Metode Pengumpulan Bahan Hukum}

Metode yang digunakan dalam memperoleh bahan hukum adalah dengan menggunakan studi penyusunan pustaka. Studi ini adalah merupakan proses pengumpulan bahan hukum yang berkaitan dengan kebijakan yuridis yang berkaitan dengan masyarakat hukum adat yang antara lain dilakukan dengan mempelajari

\footnotetext{
${ }^{7}$ Abdulkadir Muhammad, Op.Cit; 113.
} 
literatur, karya ilmiah, majalah, koran, arsip dan manuskrip.

\section{Analisis Bahan Hukum}

Untuk memperoleh kesimpulan, bahan dari studi pustaka untuk di analisis secara kualitatif dan diuji dengan menggunakan interpretasi sistematis. Dimana dengan bertitik tolak dari sistem aturan mengartikan suatu ketentuan hukum untuk menjawab permasalahan yang ada.

\section{HASIL PENELITIAN DAN PEMBAHASAN}

\section{A. Legitimasi Masyarakat Hukum Adat}

Dalam peraturan perundangundangan di Indonesia mengenal hukum adat dan masyarakat hukum adat dengan dua istilah baik sebagai masyarakat hukum adat atau adatrecht tsgemeenschap dan sebagai Indigenous People. Selain kedua istilah ini juga dikenal istilah masyarakat tradisional sebagaimana yang tercantum dalam pasal $28 \mathrm{I}$ ayat 3 yang esensinya sama dengan masyarakat adat. Dalam perkembangannya berdasarkan pasal $18 \mathrm{~B}$ ayat (2) UUD 1945, pengakuan masyarakat adat bergeser dari yang bersifat deklaratif menjadi bersyarat. Berikut berbagai peraturan perundang-undangan di Indonesia yang melegitimasi keberadaan Masyarakat Hukum Adat serta pemenuhan hak-haknya:

\section{UUD Negara Republik Indonesia Tahun 1945}

\section{a. Pasal 18B Ayat 2}

Negara mengakui dan menghormati kesatuan masyarakat hukum adat beserta hak-hak tradisionalnya sepanjang masih hidup dan sesuai dengan perkembangan masyarakat dan prinsip negara kesatuan republik Indonesia yang diatur dalam Undang-undang. Pasal ini adalah salah satu landasan konstitusional masyarakat adat yang menyatakan pengakuan secara deklaratif bahwa negara mengakui dan menghormati keberadaan dan hak-hak masyarakat adat. namun pengakuan tersebut memberikan batasan atau persyaratan agar suatu komunitas dapat diakui keberadaannya sebagai masyarakat adat.

Berdasarkan rumusan tersebut maka ada 4 unsur yang harus diperhatikan sebagai syarat eksistensi masyarakat hukum adat di Indonesia, antara lain:

- Sepanjang masih hidup

- Sesuai dengan perkembangan masyarakat

- Prinsip Negara kesatuan Republik Indonesia

- Yang diatur dalam Undang-undang

Terlepas dari berbagai kritik terhadap rumusan pasal ini, namun pasal 18 B ayat (2) mengamanatkan bahwa pengakuan dan perlindungan masyarakat adat diatur undang-undang. Hal ini berarti bahwa penjabaran ketentuan tentang pengakuan dan perlindungan mayarakat dan hukum adat harus dibuat dalam satu Undang-Undang tersendiri. Karena undang-undangnya belum terbentuk, sementara ini merupakan kebutuhan mendesak, maka banyak ditemukan peraturan perundang-undangan lahir sebelum ada Undang-Undang. Untuk itu dibenarkan bahwa pengaturannya termasuk tentang masyarakat adat ditetapkan dengan peraturan pemerintah dan peraturan daerah sepangang peraturan tersebut menjamin kepastian hukum yang berkeadilan. Pasal 18 ini masuk dalam bab tentang pemerintahan daerah, sehingga dapat disimpulkan bahwa pemerintah daerah memiliki kewenangan dalam penyusunan ketentuan yang memberikan pengakuan dan perlindungan bagi masyarakat adat berdasarkan putusan Mahkamah Konstitusi bahwa sepanjang peraturan tersebut 
menjamin kepastian hukum yang berkeadilan.

\section{b. Pasal 28I ayat (3) UUD 1945}

Identitas budaya dan hak masyarakat tradisional dihormati selaras dengan perkembangan zaman dan peradaban. Hal ini adalah pendektan HAM dimana nampak jelas dalam sistematika UUD 1945 yang meletakkan psal 28I ayat (3) UUD 1945 di dalam Bab tentang Hak asasi manusia bersamaan dengan hak yang lainnya.

\section{c. Pasal 32 Ayat (1) dan (2) UUD 1945}

Pasal 32 Ayat (1); Negara memajukan kebudayaan nasional indonesua ditengah peradaban dunia dengan menjamin keberadaan masyarakat dalam memelihara dan mengembangkan nilai budanyaya. Sementara dalam pasal 32 ayat (2) ; Negara menghormati dan memelihara bahasa daerah sebagai kekayaan budaya nasional. Kedua pasal ini tidak terkait langsung dengan hak masyarakat adat atas sumber daya alam. Namun dalam kehidupan masyarakat adat, pola-pola pengelolaan sumberdaya alam tradisional menjadi budaya tersendiri yang berbeda dengan pola-pola yang dikembangkan oleh masyarakat industri. Pola-poal inilah yang menjadi kearifan tradisional atau kearifan lokal masyarakat dalam pengelolaan sumber daya alam dan lingkungan hidup.

Ketentuan ini menjadi landasan konstitusional dalam melihat masyarakat dari dimensi kebudayaan. Hak yang diatur dalam ketentuan ini yaitu hak untuk mengembangkan nilai-nili budaya dan bahasa daerah. Dan pendekatan ini adalah pendektan yang paling aman dilakukan bagi pemerintah karena resiko pendekatan ini tidak lebih besar dibandingkan dengan pendekatan lainnya.

\section{d. Ketetapan MPR No.} XVII/MPR/1998 tentang Hak Asasi Manusia

Pasal 41 dari piagam HAM yang merupakan bagian yang tidak terpisahkan dari ketetapan ini menyatakan identitas budaya masyarakat tradisional termasuk atas tanah hak ulayat dilindungi selaras dengan perkembangan zaman.

\section{e. Ketetapan MPR No. IV/MPR/1999 tentang Garis-Garis Besar Haluan Negara 1999-2004}

Dalam bidang pembangunan ekonomi ditemukan arahan mengembangkan kebijakan pertanahan untuk meningkatkan pemanfaatan dan penggunaan tanah secara adil transparan dan produktif sengan mengutamakan hak-hak rakyat setempat termasuk hak ulayat dan masyarakat adat serta berdasarkan tata ruang wilayah yang serasi dan seimbang.

\section{f. Ketetapan MPR No. IX/MPR/2001} tentang Pembaruan Agraria dan Pengelolaan Sumber daya Alam

Salah satu prinsip yang menjadi landasannya adalah seperti yang dicantumkan dalam pasal 4 huruf $\mathrm{j}$ yang menyatakan mengakui, menghormati, dan melindungi masyarakat hukum adat dan keragaman budaya bangsa atas sumber daya alam/agraria.

\section{g. Undang-Undang No. 5 tahun 1960 Tentang Peraturan Dasar Pokok Pokok Agraria \\ Undang-Undang ini pada dasarnya} dimaksudkan sebagai pelaksanaan lebih lanjut pasal 33 ayat (3) UUD 1945 Sebagaimana yang tercantum dalam pasal 2 ayat (1). (2), dan (3). Sedangkan pada ayat (4) dinyatakan bahwa; hak menguasai 
negara diatas pelaksanaannya dapat dikuasakan kepada daerah daerah swatantra dan masyarakat hukum adat, sekedar diperlukan dan tidak bertentangan dengan kepentingan nasional menurut ketentuan peraturan pemerintah.

Dalam Pasal 3 dinyatakan bahwa; dengan mengingat ketentuan dalam pasal 1 dan 2 pelaksanaan hak ulayat dan hak-hak yang serupa itu dari masyarakat hukum adat, sepanjang menurut kenyataannya masih ada, harus sedemikian rupa sehingga sesuai dengan kepentingan nasional dan negara, yang berdasarkan atas persatuan bangsa serta tidak boleh bertentangan dengan Undang-undang dan peraturan yang lebih tinggi.

\section{h. Undang-Undang No. 5 Tahun 1990 Tentang Konservasi Sumber Daya Alam Hayatai dan Ekosistemnya}

Undang-undang ini mengatur konservasi sumber daya alam hayati dan ekosistemnya yang bertujuan untuk mengusahakan terwujudnya kelestarian sumber daya alam hayati serta keseimbangan ekosistemnya melalui kegiatan perlindungan sistem penyangga kehidupan, pengawetan keanekaragaman jenis tumbuhan dan satwa beserta ekosistemnya serta pemanfaatan secara lestari sumber daya tersebut. Materi pengaturan undang-undang ini menjadi salah satu pedoman utama dalam menyusun kebijakan pengaturan tradisional terkait sumber daya genetik.

\section{i. Undang Undang Nomor 10 tahun 1992 tentang Kependudukan dan Keluarga Sejahtera}

Penegasan terhadap hak masyarakat adat untuk hidup dengan identitas budaya yang khas tersebut juga ditegaskan dalam undang-undang ini. Hak penduduk sebagai anggota masyarakat, seperti yang ditentukan dalam Pasal 6 huruf b
UUPKPKS, mencakup hak untuk mengembangkan kekayaan budaya, hak untuk mengembangkan kemampuan bersama sebagai kelompok, hak atas pemanfaatan wilayah warisan adat, dan hak untuk melestarikan atau mengembangkan perilaku kehidupan budayanya. Menurut penjelasan Pasal ini, hak untuk melestarikan dan mengembangkan perilaku kehidupan budaya meliputi aspek fisik (hubungan dengan tanah), maupun aspek nonfisik, termasuk sosial budaya seperti kekhasan cara hidup. Dengan demikian, dalam Pasal 6 huruf $b$ beserta penjelasannya, dari sudut perundangundangan diberikan kedudukan kuat kepada penduduk asli/suku atau kelompok dengan kehidupan yang khas untuk mempertahankan cara hidupnya, termasuk kegiatan pelestarian lingkungan yang meliputi perlindungan keragaman hayati.

\section{j. Undang-Undang No. 39 Tahun} 1999 Tentang Hak Asasi Manusia

Undang-undang ini merupakan undang-undang pertama yang dilahirkan oleh pemerintah untuk mengatur hak asasi manusia dalam cakupan yang lebih luas. UU ini lahir atas tuntutan penguatan kewajiban negara dalam menghormati, melindungi dan memenuhi HAM warga negara. Pembuatan UU HAM semakin dipercepat karena ada keinginan untuk menegaskan komitmen negara dalam perlindungan HAMyang selama Orde Baru sempat terabaikan. Substansi dari UU ini diambil dari TAPMPRNo.XVII/MPR/ 1998 tentang Hak Asasi Manusia. Sejumlah ketentuan yang dapat dikaitkan dengan keberadaan dan hak-hakmasyarakat adat terlihat dalam Pasal 5 ayat (3); Setiap orang termasuk kelompok masyarakat yang rentan berhak memperoleh pengakuan dan perlindungan lebih berkenaan dengan kekhususannya. Pasal 6 ayat (1); Dalam rangka penegakan hak asasi manusia, 
perbedaan dan kebutuhan dalam masyarakat hukum adat harus diperhatikan dan dilindungi oleh hukum,masyarakat dan pemerintah serta pasal 6 ayat (2); Identitas budaya masyarakat huk um adat, termasuk hak atas tanah ulayat dilindungi, selaras dengan perkembangan zaman.

Pasal 5 ayat (3) UU HAM mengatur lebih luas bagi kelompok yang memiliki kekhususan. Masyarakat adat hanya salah satu kelompok yang memiliki kekhususan karena berbeda dengan masyarakat pada umumnya. Perbedaan itu antara lain soal hubungan sosial, politik dan ekologis dengan alam. Selain masyarakat adat, kelompok masyarakat rentan yang memiliki kekhususan misalkan perempuan, anakanak, kelompok tunarungu dan lain-lainnya.

Kemudian Pasal 6 ayat (1) UU HAM mulai masuk mengidentifikasi masyarakat adat. Ketentuan ini menekankan pentingnya pemenuhan kebutuhan yang berbeda dari masyarakat adat yang harus diperhatikan dan dilindungi oleh hukum, masyarakat dan pemerintah. Terakhir Pasal 6 ayat (2) UU HAM lebih spesfiik menyebutkan jenis hak-hak masyarakat adat yang harus dilindungi oleh negera antara lain identitas budaya dan hak atas tanah ulayat.

\section{k. Undang-Undang No. 41 Tahun 1999 Tentang Kehutanan}

Pada Pasal 4 ayat (3) ditegaskan bahwa penguasaan hutan oleh negara tetap memperhatikan hak masyarakat hukum adat sepanjang kenyataannya tidak bertentangan dengan kepentingan nasional. Kemudian dalam Pasal 5 ayat (2) disebutkan bahwa hutan negara dapat berupa hutan adat. Sedang dalam ayat (3) dinyatakan bahwa Pemerintah menetapkan hutan adat sepanjang menurut kenyataannya masyarakat hukum adat yang bersangkutan masih ada dan diakui keberadaannya. Dan apabila dalam perkembangannya masyarakat hukum adat yang bersangkutan tidak ada lagi, maka hak pengelolaan hutan adat kembali kepada Pemerintah (ayat [4]).

Pasal 1 angka 6 menyatakan bahwa hutan adat adalah hutan negara yang berada di wilayah masyarakat hukum adat yang pada penjelasan pasal 5 ayat (1) tersebut bahwa hutan negara dapat berupa hutan adat, yakni hutan negara yang diserahkan pengelolaannya kepada masyarakat adat. hutan tersebut sebelumnya hutan ulayat, hutan marga, hutan pertuanan atau sebutan lainnya. Berdasarkan putusan Mahkamah Konstitusi Nomor; 35/PUU-IX/2012 pasal 1 angka 6 dan penjelasan pasal 5 ayat (1) dibatalkan sehingga hutan adat bukan lagi hutan negara melainkan hutan yang berada dalam wilayah masyarakat hukum adat.

Pasal 67 mengatur mengenai hak masyarakat hukum adat sepanjang kenyataannya masih ada dan diakui keberadannya. Dalam penjelasannya disebutkan masyarakat hukum adat diakui jika memenuhi syarat:

a. Masyarakatnya masih dalam bentuk paguyuban (rechtsgemeenschap)

b. Ada kelembagaan dalam bentuk perangkat penguasa adatnya

c. Ada wilayah hukum adat yang jelas

d. Ada pranata dan perangkat hukum khususnya peradilan adat yang masih ditaati

e. Masih mengadakan pemungutan hasil hutan di wilayah hutan sekitarnya untuk pemenuhan kebutuhan hidup sehari-hari

Keempat syarat ini masih belum memiliki penjelasan lengkap dan resmi, sehingga belum diadakan inventarisasi resmi terhadap masyarakat hukum adat yang memenuhi empat syarat tersebut

\section{Undang-Undang Nomor 18 Tahun 2004 Tentang Perkebunan}

Undang-undang ini mewajibkan kepada pengusaha yang mengajukan 
permohonan hak atas satu wilayah tertentu untuk terlebih dahulu melakukan musyawarah dengan masyarakat hukum adat yang memegang hak ulayat atas suatu wilayah. Hal ini secara tegas disebutkan dalam Pasal 9 ayat (2) yang berbunyi sebagai berikut: dalma tanah yang diperlukan merupakan tanah ulayat masyarakat adat yang menurut kenyataannya masih ada, mendahului pemberian hak sebagaimana dimaksud dalam ayat (1), pemohon hak wajib melakukan musyawarah dengan masyarakat hukum adat pemegang hak ulayat dan warga pemegang hak atas tanah yang bersangkutan untuk memperoleh kespakatan mengenai penyerahan tanah dan imbalannya.

Ketentuan ini memposisikan kepentingan masyarakat adat atas suatu wilayah bukan sebagai hak yang harus diperkuat, melainkan sebagai hak yang harus dilepaskan dengan kompensasi gantirugi. Dengan demikian hak amasyarakat adat atas wilayah kehidupannya tidak menjadi hal utama sebab yang lebih diutamakan adalah kepentingan perkebuna. Namun hak masyarakat adat tetap diberikan dengan ganti kerugian bila wilayahnya dijadikan sebagai wilayah perkebunan.

\section{m. Undang-Undang Nomor 11 Tahun 2005 Tentang Pengesahan Internasional Covenant on economic, social, and cultural rights (konvenan internasional tentang hak hak ekonomi sosial dan budaya) \\ Pasal 6 sampai dengan pasal 115} undang-undang ini berisikan pengakuan terhadap hak asasi setiap orang di bidang ekonomi, sosial dan budaya yaitu pekerjaan, menikmati kondisi kerja yang adil, ikut sarikat pekerja, jaminan sosial dan sebagainya,

\section{n. Undang-Undang Nomor 26 Tahun 2007 Tentang Penataan Ruang}

Menurut penjelasan undang-undang ini bahwa dalam rangka mencapai tujuan penyelenggaraan penataan ruang tersebut, Undang-Undang ini, memuat ketentuan pokok sebagai berikut, antara lain: hak, kewajiban, dan peran masyarakat dalam penyelenggaraan penataan ruang untuk menjamin keterlibatan masyarakat, termasuk masyarakat adat dalam setiap proses penyelenggaraan penataan ruang. Selain itu, pengajuan dan perlindungan terhadap masyarakat hukum adat juga dapat ditemukan dalam penjelasan Pasal 5 ayat 5 yang memasukkan kawasan adat tertentu sebagai kawasan strategis dari sudut kepentingan sosial dan budaya.

Hal yang sama juga disebutkan dalam Pasal 7 ayat (3) dimana dipaparkan bahwa penyelenggaraan penataan ruang dilakukan dengan tetap menghormati hak yang dimiliki orang sesuai dengan ketentuan peraturan perundang-undangan.

Penjelasan ayat tersebut menyatakan bahwa hak yang dimiliki orang mencakup pula hak yang dimiliki masyarakat adat sesuai dengan ketentuan peraturan perundang-undangan.

\section{o. Undang-Undang No, 32 Tahun 2009 Tentang Perlindungan dan Pengelolaan Lingkungan Hidup \\ Undang-undang ini merupakan} pengganti UU No. 23 Tahun 1997 tentang Pengelolaan Lingkungan Hidup.Undangundang ini mengikuti arus legalisasi masyarakat adat di dalam undang-undang terkait dengan sumber daya alam dan lingkungan yang banyak terjadi setelah 1998. Undang-undang ini tidak memakai istilah masyarakat hukum adat tetapi meniru definisi yang sebagaimana definisi masyarakat adat dalam UU Pengelolaan Wilayah Pesisir dan Pulau-Pulau Kecil 
yang tidak memberikan sejumlah kriteria atau persyaratan terhadap keberadaan masyarakat adat berserta dengan hak-hak tradisionalnya. Lalu di dalam menjelaskan pembagian kewenangan pemerintah dalam perlindungan dan pengelolaan lingkungan hidup diatur tugas pemerintah dan pemerintah daerah terkait dengan keberadaan, hak-hak dan kearifan lokal masyarakat adat. Dalam Pasal 63 ayat (1), ayat (2) dan ayat (3). Pembagian tugas dan wewenang tersebut sebagai berikut:

a. Pemerintah, menetapkan kebijakan mengenai tata cara pengakuan keberadaan masyarakat hukum adat, kearifan lokal, dan hak masyarakat hukum adat yang terkait dengan perlindungan dan pengelolaan lingkungan hidup.

b. Pemerintah Provinsi, menetapkan kebijakan mengenai tata cara pengakuan keberadaan masyarakat hukum adat, kearifan lokal, dan hak masyarakat hukum adat yang terkait dengan perlindungan dan pengelolaan lingkungan hidup pada tingkat provinsi.

c. Pemerintah Kabupaten/ Kota, melaksanakan kebijakan mengenai tata cara pengakuan keberadaan masyarakat hukum adat, kearifan lokal, dan hak masyarakat hukum adat yang terkait dengan perlindungan dan pengelolaan lingkungan hidup pada tingkat kabupaten/ kota.

\section{p. Undang-Undang Nomor 45 Tahun 2009 tentang Perikanan}

Pasal 6 undang-undang ini menyatakan bahwa pengelolaan perikanan untuk kepentingan penangkapan dan pembudidayaan ikan harus mempertimbangkan Hukum Adat dan Kearifan Lokal serta memperhatikan peran serta masyarakat. Hak ulayat Masyarakat Hukum Adat atas Sumber Daya Alam sebagaimana yang dimaksud pada Pasal 6 ayat (2) tetap diakui sepanjang kenyataannya masih ada dan telah dikukuhkan dalam Peraturan Daerah (Perda) setempat sebagaimana diatur dalam Pasal 6 ayat (3).

\section{q. Undang-Undang Nomor 6 Tahun 2014 Tentang Desa}

Dengan konstruksi menggabungkan fungsi self-governing community dengan local self government, diharapkan kesatuan masyarakat hukum adat yang selama ini merupakan bagian dari wilayah Desa, ditata sedemikian rupa menjadi Desa dan Desa Adat. Desa dan Desa Adat pada dasarnya melakukan tugas yang hampir sama. Sedangkan perbedaannya hanyalah dalam pelaksanaan hak asal-usul, terutama menyangkut pelestarian sosial Desa Adat, pengaturan dan pengurusan wilayah adat, sidang perdamaian adat, pemeliharaan ketenteraman dan ketertiban bagi masyarakat hukum adat, serta pengaturan pelaksanaan pemerintahan berdasarkan susunan asli.

Desa Adat memiliki fungsi pemerintahan, keuangan Desa, pembangunan Desa, serta mendapat fasilitasi dan pembinaan dari pemerintah Kabupaten/Kota. Dalam posisi seperti ini, Desa dan Desa Adat mendapat perlakuan yang sama dari Pemerintah dan Pemerintah Daerah. Oleh sebab itu, di masa depan Desa dan Desa Adat dapat melakukan perubahan wajah Desa dan tata kelola penyelenggaraan pemerintahan yang efektif, pelaksanaan pembangunan yang berdaya guna, serta pembinaan masyarakat dan pemberdayaan masyarakat di wilayahnya.

Desa Adat akan diakui apabila memiliki kesatuan masyarakat adat. Kesatuan masyarakat adat harus memiliki unsur; mempunyai wilayah adat, pemerintahan adat, benda/harta adat, 
hukum adat, sebagaimana yang dimaksud dalam pasal 1 ayat 1 UU Desa. UU desa juga mengakui hak-hak kesatuan masyarakat adat. Desa Adat bukan hanya bertujuan untuk mengakui hak-hak ulayat masyarakat adat, tetapi juga undang-undang ini mengatur agar masyarakata adat bisa mengurus dirinya sendiri.

\section{r. Undang-Undang 23 Tahun 2014 Tentang Pemerintahan Daerah}

Sebagaimana diketahui bahwa Undang-undang pertama yang mengatur tentang Pemerintahan Daerah yang lahir setelah reformasi adalah Undang-Undang No. 22 tahun 1999 tentang Pemerintahan Daerah. Kemudian diubah dengan UndangUndang No. 32 tahun 2004 tentang Pemerintah Daerah. Pengaturan tentang masyarakat adat tampak jelas di dalam Undang-Undang No. 32 tahun 2004 yang dipengaruhi oleh hasil amandemen UUD 1945. Salah satu pengaruh tersebut nampak dalam Pasal 2 ayat (9) : Negara mengakui dan menghormati kesatuan-kesatuan masyarakat hukum adat beserta hak tradisionalnya sepanjang masih hidup dan sesuai dengan perkembangan masyarakat dan prinsip negara kesatuan republik Indonesia. Ketentuan ini kemudian dihilangkan dengan adanya UndangUndang 23 Tahun 2014 tentang pemerintah daerah.

Dalam Undang-undang yang baru, kita bisa melihat bahwa aturan mengenai masyarakat adat diserahkan kepada pemerintah pada berbagai tingkatan untuk berbagai urusan. Pada pembagian urusan pemerintahan dibidang sosial khususnya bidang pemberdayaan sosial diatur bahwa pemerintah pusat berkaitan dengan penetapan lokasi dan pemberdayaan sosial komunitas adat terpencil (KAT). Sementara urusan pelaksanaan di lapangan mengenai pemberdayaan sosial KAT diserahkan pada pemerintah kabupaten/kota.
Pada sub bagian pengakuan keberadaan masyarakat hukum adat, kearifan lokal, hak MHA terkait PPLH pemerintah daerah kabupaten bertugas dalam hal :

a. Penetapan pengakuan MHA, kearifan lokal atau pengetahuan tradisional dan hak kearifan lokal atau pengetahuan tradisional dan hak MHA terkait dengan PPLH yang berada di Daerah kabupaten/ kota.

b. Peningkatan kapasitas MHA, kearifan lokal atau pengetahuan tradisional dan hak kearifan lokal atau pengetahuan tradisional dan hak MHA terkait dengan PPLH yang berada di Daerah kabupaten/ kota.

Pada sub urusan "Lembaga Kemasyarakatan, Lembaga Adat, dan Masyarakat Hukum Adat" Undang-undang ini mengatur pembagian urusan pada masing-masing level pemerintahan sebagai berikut:

Pemerintah Provinsi bertugas melaksanakan Pemberdayaan lembaga kemasyarakatan yang bergerak di bidang pemberdayaan Desa dan lembaga adat tingkat Daerah provinsi serta pemberdayaan masyarakat hukum adat yang masyarakat pelakunya hukum adat yang sama berada di lintas Daerah kabupaten/kota.

Pemerintah Kabupaten/Kota bertugas untuk melaksanakan dua hal, yaitu:

a. Pemberdayaan lembaga kemasyarakatan yang bergerak di bidang pemberdayaan Desa dan lembaga adat tingkat Daerah kabupaten/kota dan pemberdayaan masyarakat hukum adat yang masyarakat pelakunya hukum adat yang sama dalam Daerah kabupaten/kota. 
b. Pemberdayaan lembaga kemasyarakatan dan lembaga adat tingkat Desa.

Dari uraian tersebut di atas, maka sebenarnya dapat terlihat bahwa sangat banyak peraturan perundang-undangan yang dibuat dan diundangkan oleh pemerintah terkait dengan keberadaan masyarakat dan upaya untuk pemenuhan hak-haknya khususnya yang berkaitan dengan hak dalam sumber daya alam, yang dimana antara masyarakat hukum adat dan alam dan kekayaannya tidak dapat dipisahkan. Legitimasi yang diberikan oleh negara terhadap masyarakat hukum adat yang terdapat dalam berbagai peraturan perundang-undangan tersebut di atas merupakan modal awal bagi pemerintah dan khususnya masyarakat hukum adat dalam menjaga eksistensinya.

\section{B. Implementasi Peran Negara Dalam Menjaga Eksistensi Masyarakat Hukum Adat}

Sebagaimana telah disinggung pada pembahasan sebelumnya bahwa negara mendapatkan amanah dari Konstitusi untuk mengakui dan menghormati kesatuan Masyarakat Hukum Adat beserta hak-hak tradisionalnya. Amanah tersebut secara teknis dilaksanakan oleh pemerintah sebagai penyelenggara negara. Sebagai penyelenggara negara ini kemudian negara bertanggungjawab atas amanah yang oleh konstitusi diberikan kepada negara. Dalam konteks penyelenggaraan negara, pemerintah pusat membagi/melimpahkan kewenangan yang dimiliki kepada pemerintah daerah sebagai konsekwensi dari penerapan desentralisasi dalam urusan pemerintahan yang terkemas dalam konsep otonomi daerah. Dalam berbagai literature, ada beberapa bentuk pelimpahan kewenangan yang dikenal, yaitu: atribusi, delegasi dan mandat. ${ }^{8}$

Di Indonesia, Otonomi Daerah sudah mendapat perhatian khusus bahkan sebelum periode Orde Baru berkuasa. Tercatat ada beberapa Undang- Undang atau peraturan yang dikeluarkan pemerintah yang menyangkut hal ini. ${ }^{9}$ Pada masa Orde Baru sesuai dengan pelaksanaan Undang-Undang No. 5 Tahun 1974 Tentang Pokok-Pokok Pemerintahan di Daerah, pelaksanaan Otonomi Daerah juga diterapkan akan tetapi hasilnya tidak sesuai dengan yang diharapkan. Kemudian pada awal-awal reformasi yaitu tahun 1999 lahir UndangUndang Nomor 22 tahun 1999 tentang Pemerintahan Daerah yang menggantikan undang undang sebelumnya. Namun dalam pelaksanaan Undang-Undang Nomor 22 tahun 1999 masih ditemukan berbagai kekurangan sehingga digantikan dengan Undang-Undang No. 32 Tahun 2004 Tentang Pemerintahan Daerah. Dan pada tahun 2014 akhirnya undang-undang ini kemudian tidak berlaku lagi dan dicabut dengan berlakunya Undang-Undang Nomor 23 Tahun 2014 Tentang Pemerintahan Daerah. Pencabutan ini dilakukan karena undang-undang tersebut dianggap tidak sesuai lagi dengan perkembangan keadaan, ketatanegaraan dan tuntutan penyelenggaraan pemerintahan daerah.

Lahirnya Undang-Undang Nomor 23 Tahun 2014 Tentang Pemerintahan Daerah ini kemudian menjadi dasar hukum yang hingga kini berlaku yang mengatur tentang pemerintahan daerah dengan beberapa perubahan dan penyesuaian yang dilakukan, terakhir undang-undang ini diubah dengan Undang-Undang Nomor 9 Tahun 2015

\footnotetext{
${ }^{8}$ Ridawan HR. Hukum Administrasi Negara.Jakarta: Rajawali Pers. 2016. Hal 101-102.

9 Sujamto, Otonomi Daerah Yang Nyata Dan Bertanggung Jawab, edisi revisi(Jakarta, Ghalia Indonesia, 1990), hlm. 101-121.
} 
tentang Perubahan Kedua Atas UndangUndang Nomor 23 Tahun 2014 tentang Pemerintahan Daerah. Dalam undangundang ini kemudian dijabarkan tentang pembagian kewenangan yang dimiliki oleh Pemerintah Pusat, Pemerintah Provinsi dan Pemerintah Kabupaten/Kota dalam hal pengakuan dan perlindungan terhadap masyarakat hukum adat. Hal ini sebagaimana yang terlampir dalam lampiran huruf $(\mathrm{K})$ tentang Pembagian Urusan Pemerintahan Dibidang Lingkungan Hidup pada angka (7) mengenai Pengakuan keberadaan masyarakat hukum adat (MHA), kearifan lokal dan hak MHA yang terkait dengan PPLH.

Hingga saat ini sebagai bentuk peran negara dalam menjaga eksistensi masyarakat hukum adat, pemerintah melalui Menteri Dalam Negeri telah mengeluarkan suatu pedoman untuk memberikan pengakuan dan perlindungan terhadap masyarakat hukum adat berupa Peraturan Menteri Dalam Negeri Nomor 52 Tahun 2014 Tentang Pedoman Pengakuan Dan Perlindungan Masyarakat Hukum Adat. Permendagri ini kemudian menjadi salah satu landasan hukum bagi negara (pemerintah maupun pemerintah daerah) untuk menjamin eksistensi masyarakat hukum adat termasuk pemenuhan segala hak-hak yang dimilikinya. Lahirnya permendagri ini sebagai bentuk tindak lanjut dan upaya dari negara dalam mewujudkan amanah konstitusi sebagaimana yang ditegaskan dalam Pasal 18 b ayat (2).

Peraturan menteri ini menjadi dasar dan pedoman bagi kepala daerah (Gubernur dan Bupati/Walikota) untuk melakukan pengakuan dan perlindungan masyarakat hukum adat. Dalam ketentuan permendagri ini langkah pertama yang harus dilakukan oleh kepala daerah (Bupati/Walikota) adalah membentuk Panitia Masyarakat Hukum Adat kabupaten/kota yang ditetapkan dengan Keputusan Bupati/Walikota. Struktur organisasi dari kepanitiaan yang dibentuk ini terdiri dari:

a. Sekretaris Daerah kabupaten/kota sebagai ketua;

b. Kepala SKPD yang membidangi pemberdayaan masyarakat sebagai sekretaris;

c. Kepala Bagian Hukum sekretariat kabupaten/kota sebagai anggota;

d. Camat atau sebutan lain sebagai anggota; dan

e. Kepala SKPD terkait sesuai karakteristik masyarakat hukum adat sebagai anggota.

Panitia yang telah terbentuk nantinya akan melakukan tahapan-tahapan pengakuan dan perlindungan Masyarakat Hukum Adat. Ada 3 (tiga) tahapan yang diatur dalam permendagri ini, yaitu:

a. Identifikasi Masyarakat Hukum Adat;

b. Verifikasi dan validasi Masyarakat hukum Adat;

c. Penetapan Masyarakat Hukum Adat.

Tahap identifikasi dilakukan untuk mencermati hal-hal yang berkaitan dengan masyarakat hukum adat, diantaranya:

1. Sejarah masyarakat hukum adat;

2. Wilayah adat;

3. Hukum adat;

4. Harta kekayaan dan/atau benda-benda adat; dan

5. Kelembagaan/sistem pemerintahan adat.

Identifiksai ini dilakukan oleh camat setempat atau sebutan lain dengan melibatkan masyarakat hukum adat atau kelompok masyarakat. Hasil dari identifikasi yang dilakukan kemudian disampaikan kepada panitia masyarakat hukum adat untuk melakukan tahapan berikutnya.

Atas hasil identifikasi yang telah dilakukan, panitia masyarakat hukum adat kabupaten/kota melanjutkan kegiatan ketahap berikutnya dengan melakukan 
tahap verifikasi dan validasi, tahapan ini penting untuk mencocokkan hasil identifikasi yang dilakukan oleh camat setempat yang dibantu oleh masyarakat hukum adat atau kelompok masyarakat dengan fakta yang ada dilapangan, sehingga memang terjadi kesesuaian. Setelah dilakukan verifikasi dan validasi hasilnya kemudian diumumkan kepada masyarakat hukum adat setempat.

Tahap penetapan masyarakat hukum adat adalah tahapan terakhir dari pedoman pengakuan dan perlindungan terhadap masyarakat hukum adat. Pada tahapan ini, Hasil verifikasi dan validasi kemudian disampaikan kepada bupati/walikota oleh panitia masyarakat hukum adat dalam bentuk rekomendasi. Terhadap rekomendasi yang disampaikan tersebut, bupati/walikota melakukan penetapan pengakuan dan perlindungan masyarakat hukum adat. Dan dalam hal masyarakat hukum adat berada pada 2 (dua) atau lebih kabupaten/kota, maka pengakuan dan perlindungan masyarakat hukum adat dilakukan/ditetapkan dengan Keputusan Bersama Kepala Daerah. melakukan penetapan pengakuan dan perlindungan masyarakat hukum adat berdasarkan rekomendasi Panitia Masyarakat Hukum Adat dengan Keputusan Kepala Daerah.

Dari uraian di atas, terlihat bahwa pelaksanaan secara teknis terhadap pengakuan dan perlindungan masyarakat hukum adat ada pada pemerintah daerah yaitu kabupaten/kota. Namun demikian bukan berarti bahwa pemerintah pusat tidak memiliki andil dalam upaya memberikan pengakuan dan perlindungan terhadap masyarakat hukum adat. Peran dari pemerintah pusat sebagaimana yang diatur dalam permendagri ini adalah melakukan pembinaan dan pengawasan dalam pelaksanaan pengakuan dan perlindungan masyarakat hukum adat yang secara teknis dilakukan oleh menteri dalam negeri melalui Direktorat Jenderal Pemberdayaan Masyarakat.

Berlakunya Permendagri Nomor 52 ini tentu membawa angin segar bagi komunitas masyarakat hukum adat, sebab dengan demikian akan ada kejelasan dan kepastian hukum terhadap keberadaan mereka yang selama ini belum mendapat pengakuan dan perlindungan secara nyata dari negara melalui pemerintah, khususnya mengenai lima (5) hal sebagaimana yang telah dikemukakan di atas, yaitu:

1. Sejarah masyarakat hukum adat;

2. Wilayah adat;

3. Hukum adat;

4. Harta kekayaan dan/atau benda-benda adat; dan

5. Kelembagaan/sistem pemerintahan adat.

Selama ini, hal yang masih menjadi sumber konflik utama yang terjadi pada masyarakat hukum adat adalah mengenai wilayah adatnya, kendala yang dihadapi oleh masyarakat hukum adat yaitu ketidakjelasan mengenai luas dan batas wilayah adat yang mereka kuasai sehingga ketika ada pihak lain di luar persekutuan mereka yang mengklaim wilayah adat mereka, posisi masyarakat hukum adat cenderung lemah di hadapan hukum. Olehnya itu, dengan adanya permendagri ini, ketika telah dilakukan identifikasi dan ada penetapan dari kepala daerah sehingga ada kejelasan dan kepastian hukum mengenai hal-hal tersebut di atas, khususnya mengenai wilayah yang dikuasai oleh masyarakat hukum adat.

\section{PENUTUP Kesimpulan Dan Saran}

Adapun kesimpulan dalam penelitian ini bahwa Konstitusi telah menegaskan bahwa negara mengakui dan menghormati kesatuan masyarakat hukum adat beserta hak-hak tradisionalnya sepanjang masih 
hidup dan sesuai dengan perkembangan masyarakat dan prinsip Negara Kesatuan Republik Indonesia, yang diatur dalam undang-undang. Berbagai peraturan perundang-undangan kemudian dibuat dan diundangkan oleh pemerintah sebagai tindak lanjut dari amanah konstitusi tersebut. Hal tersebut menunjukkan bahwa secara yuridis negara telah berupaya untuk melaksanakan amanah yang diberikan. Pemerintah sebagai penyelenggara negara tentu memiliki tanggung jawab dan peran besar atas upaya untuk menjaga eksistensi masyarakat hukum adat. Oleh karena itu pada tahun 2014 Kementerian Dalam Negeri mengeluarkan Peraturan Menteri Dalam Negeri Nomor 52 Tahun 2014 tentang Pedoman Pengakuan dan Perlindungan Masyarakat hukum Adat. Permendagri ini secara teknis menjadi dasar bagi pemerintah, khususnya pemerintah daerah dan masyarakat hukum adat secara bersama-sama menjaga eksistensi dari masyarakat hukum adat itu sendiri melalui pengakuan dan perlindungan terhadapnya.

Adapun Saran terhadap penelitian ini bahwa Permendagri Nomor 52 Tahun 2014 tentang Pedoman Pengakuan dan Perlindungan Masyarakat hukum Adat, merupakan padoman yang dibuat oleh negara melalui kemendagri bagi pemerintah daerah, kususnya Kabupaten/Kota dalam upaya memberikan pengakuan dan perlindungan bagi masyarakat hukum adat. Oleh karena itu, dalam permendagri tersebut secara eksplisit ditegaskan bahwa kewenangan untuk pelaksanaannya ada pada kepala daerah (Bupati/Walikota), sehingga menjadi harapan besar agar pemerintah daerah melalui bupati/walikota agar dapat sesegera mungkin menindaklanjuti pedoman yang telah dibuat tersebut. Tentu ini dilakukan tidak lain adalah agar baik secara de jure maupun de facto, masyarakat hukum adat mendapatkan jaminan dari negara melalui pemerintah daerah dalam pemenuhan hak-haknya sebagai upaya menjaga eksistensi masyarakat hukum adat.

\section{DAFTAR PUSTAKA}

\section{BUKU :}

Abdulkadir Muhammad, 2004, Hukum dan Penelitian Hukum. Cet. 1, PT. Citra Aditya Bakti, Bandung.

Jhonny Ibrahim, 2006, Teori dan Metodologi Penelitian Hukum Normatif, Bayumedia Publishing, Malang.

Ridawan HR, 2016, Hukum Administrasi Negara, Rajawali Pers, Jakarta.

Siradjudin, Azmi A. R., 2010, Pengakuan Masyarakat Adat dalam Instrumen Hukum Nasional, Yayasan Merah Putih, Sulawesi Tengah.

Sujamto, 1990, Otonomi Daerah Yang Nyata Dan Bertanggung Jawab, edisi revisi, Ghalia Indonesia, Jakarta.

Suharsimi Arikunto, 2002, Prosedur Penelitian: Suatu Pendekatan Praktek, Rieneka Cipta, Jakarta.

Sumardjani, Lisman, 2007, Konflik Sosial Kehutanan, Bogor. 